\title{
Developing Talent for the Video Game Industry in Colombia: Design and Development Issues
}

\section{Desarrollo de talentos para la industria de video juegos en Colombia: Retos en su diseño y desarrollo}

\author{
Alvaro Hernán Galvis Panqueva \\ University of Los Andes. Colombia \\ a.galvis73@uniandes.edu.co \\ Pablo Figueroa Forero \\ University of Los Andes. Colombia \\ pfiguero@uniandes.edu.co \\ Marcela Díaz Osorio \\ Universidad of Los Andes. Colombia \\ m.diaz11@uniandes.edu.co
}

\begin{abstract}
Resumen
El diseño de video juegos es un dominio que trasciende los límites de una sola disciplina, pues los creadores de juegos exitosos necesitan entender cómo despertar la motivación intrínseca de los jugadores, la naturaleza creativa de la solución de problemas bajo condición de riesgo, los intricados asuntos de la interacción hombre-máquina al hacer uso de dispositivos multimedia, atendiendo los retos que presentan los ambientes colaborativos y adaptativos en tiempo real. La competencia en nichos específicos también requiere ser innovador, tener pensamiento estratégico y poner en acción sólidas práctica gerenciales. Para atender esta demanda, la Universidad de los Andes en Bogotá, Colombia, diseñó un nuevo programa de especialización para creación de video juegos. Este documento presenta el tipo de oportunidades que hay a nivel nacional e internacional para quienes desean desarrollar este tipo de talento; también discute las consideraciones curriculares e instruccionales que se tomaron en cuenta para construir un programa en modalidad mixta (blended learning) con el que se satisficiera la necesidad. Nuestro programa no fue diseñado para un mercado existente sino para uno que deseamos haya en años por venir. Se tomaron en cuenta necesidades particulares de nuestra industria, su idiosincrasia y las tensiones que conlleva tener que vender productos en mercados globales. El programa de certificación en video juegos dará a estudiantes con diferente preparación previa (diseñadores gráficos, desarrolladores músicos) un entendimiento profundo de asuntos técnicos en su campo, así como las herramienta de gerencia y emprendimiento para salir adelante en este sector. Esta propuesta también capitaliza sobre problemas auténticos que enfrentan los miembros de este sector industrial y hace uso de problemas de la vida real como pegante que articula el trabajo interdisciplinario.
\end{abstract}

\section{Palabras clave}

Industria de video juegos, creatividad, juego, juegos, video juegos, nuevas tecnologías, tecnologías interactivas, aprendizaje en modalidad mixta 


\begin{abstract}
Video game design is a promising field that transcends the limits of a single discipline. Successful game creators need to understand the intrinsic motivation of game playing, the creative nature of problem solving and risk taking, the critical issues in human-computer interaction using multimedia devices, and the challenges of real-time collaborative and adaptive organic digital environments. Competition in specific niches also requires innovation abilities, strategic thinking, and sound administrative practices. To address this demand, the University of Los Andes in Bogota, Colombia, designed and developed a new post-baccalaureate video game development program (vGAMES certification program). This paper reports on international and national opportunities for people with vGame development talent. It also discusses the curricular and instructional design and implementation considerations involved in constructing a blended, advanced degree program based on these needs. Our program was designed not only for an existing market, but at once for the market we would like to have in some years. Specific needs from our national industry were considered, such as their indie nature, their need to sell their products in global markets, and current opportunities and challenges. The certification program will give students of different backgrounds (graphic designers, developers, and musicians) a deep understanding of technical issues in their field, as well as the necessary management and entrepreneurial tools for this sector. It also capitalizes on authentic problems faced by the video game industry and uses these real world problems as the glue between interdisciplinary coursework.
\end{abstract}

Key words

Video games industry, creativity, play, games, video games, new technologies, interactive technologies, blended learning

\title{
Introduction
}

Preparing to participate in the video game industry consists in different facets depending on the role a person wishes to play, on the niche in which they want to participate and on the opportunities, they seek to pursue locally or globally. In this paper, we describe the features of a unique $v$ Games certification program that seeks to develop students' ability to apply design thinking and agility in prototyping and the creation and commercialization of different types of video games. The program builds on the strengths that participants including programmers, graphic designers and musicians may bring to their studies. It also builds on synergies that small groups develop when they face authentic video game-related problems. The blended modality takes advantage of the opportunities provided by virtual and face-to-face learning environments. We took into account government regulations for blended programs, the mission and existing programs at our university, similar programs in our country and elsewhere, and our videogame industry and its relation to the global market.

\section{Literature Review}

Two themes in the literature contextualize the design and implementation of the vames certificate program: talent development for the video game industry, and understanding key concepts to provide a classification of games.

\section{Video game industry and talent development}

To participate in the video game industry it is important to be able to create games that can be enjoyed by the target audience. It is also necessary to be able to make a 
difference with games that target niches where one can compete and get a good share of the market. With this in mind, this section examines three experiences from countries that are pioneers in the industry and two initiatives from smaller nations.

A study about the video game industry in general refers to video games as "those games that present some kind of interactive visual display on a screen, involving pixel-based imaging. These include console-based games (for example, Sony PlayStation 2, Microsoft Xbox), handheld games (for example, Nintendo Game Boy), computer games, and video arcade games" (Izushi \& Aoyama, 2006, p. 1843).

The same study (p.1846) states that since its emergence in the 1970s, the video-game industry has quickly become a formidable in which billions of dollars are involved. By the year 2000, the United States, Japan, and United Kingdom provided 94\% of all game-software production sold worldwide (by volume), and the same three countries constituted $65 \%$ of the world's game-software market, with the United States being the largest (36\%), followed by Japan (20\%) and the United Kingdom (9\%). Human talent for game development, software creation and commercialization is one the key success factors when countries on the margin of this industry try to participate in this market.

The video game industry has grown in close collaboration with the animation industry since both make use of 2D and 3D animations. According to Tschang and Goldstein (2004), most animated series are carried by TV studios, and since these studios may be in the broadcasting rather than the production business, they rely heavily on contracting creative talent outside production studios. In fact, the film industry has outsourced their computer graphics effects for the most part. In contrast, recent 3D movie animations have largely not been outsourced, as it is the case of Pixar (Tschang and Goldstein, 2004, p. 11). In Pixar much of the creative direction focuses on executing scenes accordingly with director's decisions about how scenes should be visually, narratively, and technically carried out. Other artists, particularly at the production stage, essentially act as directed workers, filling out details on specifications from the top. This company makes it clear that their model is collaborative, and that

"All groups work closely together in an iterative process. We have a cooperative working environment and a non-hierarchical culture whereby each member of the creative team, regardless of position or department, considers the ideas of any other member of the team." (ibid)

Similarly, the video game industry demands a variety of skills, ranging from technically-oriented computer programming, to scene creating, and graphic artistry. According to Izushi and Aoyama (2006, p. 1846)

"production processes have shifted from one-person craftsmanship to an intricate division of labor. Today, the production of game software involves a team of professionals and a number of stages, starting with planning for blueprints (game titles, missions, themes, key characters, target platforms, market, and budget), scene writing, designing of character details and accessory items, and developing plans for background settings. This is followed by production of

Developing talent for the Video Game industry in Colombia: Design and development issues. Álvaro Hernán Galvis, Pablo Figueroa Forero y Marcela Díaz Osorio. 
graphic materials (from drawing to digitization), sound materials, and programming (movements and backgrounds), which are assembled by programmers importing graphic and sound materials into an 'alpha version'. After game testers have conducted debugging, a beta version is made available - first to critics and mass media for master' is issued and sent for mass production".

A comparison of video game industry strategies in Japan, the United States and the United Kingdom helps us understand how this sector has evolved internationally and offers an idea of how to nurture the video game industry with human talent in developing countries as Colombia. The following ideas are taken from Izushi and Aoyama (2006, p. 1846-1859) and explain the distinct evolutionary processes.

Japan's video-game industry drew its creative and technical talent initially from the toy industry. The sharing of artistic talent between cartoon or animated films and video games in Japan has led to a number of common features, which can be observed in the two forms of art. Many in the video-game industry refer to their interest in cartoons or animated films as being the primary motivating factor for pursuing their current occupation. The sharing of creative resources in Japan was in part possible because of the contemporaneous and overlapping development of manga (comic books), animated films, and video game industries.

Nonetheless, the video game industry had its origins in the USA and emerged with close ties to the country's budding computer industry in the 1950s and the 1960s. It drew its creative talents from the computer hardware industry, which was emerging from the Massachusetts Institute of Technology (MIT) and environs and, later, from Silicon Valley. Nolan Bushnell, the founder of Atari (founded in 1972), is known as the first entrepreneur to commercialize video games successfully. Atari benefited from the nation's top labor market in electronics hardware and software in Silicon Valley. Another firm that played a significant role for the US video-game industry was Apple Computer. This was in part because of the simultaneous evolution of video games and personal computing in Silicon Valley. An examination of the early video-game industry reveals that the industry evolved along with the personal computing industry, with its roots in "creative computing". This tradition was nurtured through the interface between computing and arcade games. The US video-game industry offered creative and alternative opportunities for engineers and programmers, many of whom had been trained in close association with the country's defence interests under the Cold War regime.

However, in spite of the powerful presence of comic books in Japan, animated films and video games in both contexts, the three sectors did not follow the same process of synergy in the United States as they did in Japan. Whereas Japan's comic book publishing peaked as recently as the mid 1990s, in the United States, the influence of comic books and animated films in popular culture peaked in the immediate post war period and had already waned by the time video games emerged.

Developing talent for the Video Game industry in Colombia: Design and development issues. Álvaro Hernán Galvis, Pablo Figueroa Forero y Marcela Díaz Osorio. 
As with the case of the United States, the video-game industry in the United Kingdom originated in computing. The British have long been regarded as pioneers in conceptualizing computing and software due to a strong tradition in mathematics. The UK video-game industry was founded on the accumulation of skills among 'bedroom coders' in the 1980s, which in turn led to its subsequent take-off in the early 1990s. The term 'bedroom coders' refers to a whole generation of self-trained programmers, mostly teenagers still in school, who programmed and ran businesses out of their bedrooms. Bedroom coders gradually disappeared from the scene with sophistication of hardware and software technologies in the 1990s. The entry of the Nintendo and Sega consoles into the UK market (both in 1987), and an increasing US interest in the UK market, meant that bedroom coders faced competition from the increasingly large-scale, formal operations of Japanese and US firms. The skills accumulation of self-trained teenage programmers was replaced by the foundation of courses on video-game design and programming by higher education institutions as well as by the entry of graduates from relevant academic subjects such as computer science and mathematics into the industry. As with the case of the United States, there is little evidence connecting the comics and animated film industries to the emergence of the video game industry in the United Kingdom.

Although economic incentives such as high wages and growth prospects undoubtedly play a role in cross-sectoral skill transfer, they do not always lead to cross-sectoral fusion of skills. Not only does the evolution of existing industries affect how and from where the emerging industry draws skills, but the socioeconomic status attached to pioneering entrepreneurs or firms in an emerging industry influences its capacity to draw skills from other sectors. What emerges from this research on the origins and the evolution of the video game industry is a new hypothesis on the interplay of economic, social, and technological factors that influence the process of cross-sectoral skill transfer. Skill formation is embedded in specific social contexts and shapes the trajectory of industry evolution in a manner unique to each country. Therefore, creating industry-specific skills out of cross-sectoral fusion of creative talent to form a new industry requires a combination of market conditions, social legitimacy, cultural cohesiveness, and the state of technologies. The sociocultural cohesiveness between old and new industries further lowers the sectoral barrier for skill transfers.

Finally, the state of technologies can also influence cross-sectoral compatibility of skills. The ascent of the Japanese video-game industry in the late 1980s came at a time when microprocessors had relatively limited power and storage media had limited capacity. These limitations were overcome by mobilizing creative talent in comic books and animated films. Technological change gradually eroded these advantages. However, combining the expertise of the US and UK video-game industries in manipulating more powerful microprocessors and larger capacity storage media with creative talent from a contents industry which is more cohesive to it, helped them to regain their competitive strengths.

A study about the animation and video game sector (AVGS) in Bogotá conducted by the Cámara de Comercio de Bogotá (Chamber of Commerce of Bogotá-Centro Nacional de Consultoría, 2010) reveals several deficiencies in the national panorama. It showed that these sectors do not have a cost structure that permits the national industry to compete internationally at the outsourcing market with Asian providers. Furthermore, there was 
no a public policy to bring in foreign investment to foster technology transfer and knowledge sharing from leading countries in the AVGS.

While the conditions promoting the growth of AVGS are poor, there is a limited internal market that could consume unique and innovative local products that could also be exported (ibid, p. 29). Internal market is served by a limited number of organizations that create video games in Bogotá (11 out of 49 in the AVGS in year 2009). These companies provided services in $90 \%$ of the cases, and a combination of products/services in the rest. Most companies (around 75\%) were micro-sized business (with less than 10 permanent workers), whereas the others were small-size business (10 to 25 permanent workers). Most companies hired temporary workers to produce a specific product, and the great majority of video game producers considered that there is good availability of human talent to collaborate in projects (ibid, p.33), such as graphic designers, industrial engineers and programmers that can be retrained as needed. Exporting companies, which are usually the small-size AVGS businesses, consider that their competitive advantage lies in the quality of their services since they compete with organizations in the service purchasing countries, not with Asian companies. Those that do not export mention that they lack commercial muscle and exporting expertise (ibid, p.39). The study suggests a set of policies to be considered by Bogotá's authorities which could form part of the national AVGS policies. In regard to talent creation for the AVGS, the proposed strategy includes complementing current training by the SENA (Servicio Nacional de Aprendizaje, a Spanish acronym for National Apprenticeship Service) about 3D animations and bilingual preparation with specialization programs that help prepare future industry workers for key roles in the AVGS (ibid, p.59).

The aforementioned initiatives in Colombia have great resonance with similar ones in countries such as Finland and Ireland, where local government has made gains in attracting and nurturing local talent for the mobile video-game industry. For example, Tekes, the Finnish government funding agency for innovation in this sector provides initial grants followed by a loan or loans for game developers with little capital. In 2012, the Helsinki government launched NewCoFactory, a new service under Enterprise Helsinki to help game developers and other industries succeed on a global scale. "It's a very good environment to be in as an investor because the companies can use the money that they're getting from investors and match that up with public funding, which decreases the risk associated to the initial investment on their investors' side" (Gaudiosi, 2014).

Another success story about nurturing local talent for game development is told by George Osborn who mentions that:

\begin{abstract}
"A ground swell of local game development talent within Ireland has begun, slowly but steadily, to form a nascent gaming community. ....The current state of the Irish games community is best seen as a young but tight-knit community of smaller (usually independent) developers, with a stronger emphasis on artistic creativity. There are a number of reasons for why this is the case. The first has been the rise of self-publishing as a general global trend since 2008. The arrival of the App Store, the growth of Steam as an indie gaming haven, and the steady
\end{abstract}


opening up of consoles has allowed developers to succeed outside of the confines of the big companies" (Osborn, 2015).

\section{Play and gaming}

Participation in the videogame industry is not only a matter of strategy and human capital. It also requires clear concepts on those elements that are behind scenes, in particular play and gaming, which are intrinsically related. A study by Huzinga (1972, p. 26) indicates that

"play is a free action, executed as such and experienced as something situated outside of normal life, but in spite of that, something that can completely absorb the player even without a material interest and without obtaining any benefit, which is executed within a determined time and place, which is developed within order and subject to rules and which gives birth to associations that tend to surround themselves with mystery or costumes for detaching oneself from the actual world."

This idea has led to the statement that even serious games - those that are not designed for commercial purposes but rather for training users on a specific skill set (Annetta, 2010)-ought to promote digital play activities, since play is a pleasurable activity that may be a motivating force in serious games (Sorensen, 2009, p. 281).

Caillois (1986, pp. 39-40) says that the multitude and infinite variety of play initially makes one lose the hope of discovering classification principles that would allow him to distribute the varieties into well-defined categories. This author proposes a bidimensional classification in which one axis represents ways of playing (paidia and ludus) and the other represents the role that characterizes the play (agon, alea, mimicry, and ilinx).

Table 1. Bidimensional classification of play, proposed by Caillois (ibid, p.79)

\begin{tabular}{|c|c|c|c|c|}
\hline WAYS OF & \multicolumn{4}{|c|}{ ROLES THAT CHARACTERIZE PLAY } \\
\hline PAIDIA & AGON & ALEA & MIMICRY & ILINX \\
\hline making noises & running & rolling dice & imitations & roller coaster \\
\hline tasting & fighting & coin flipping & illusion games & amusement park \\
\hline \multicolumn{5}{|l|}{ laughing } \\
\hline LUDUS & AGON & ALEA & MIMICRY & ILINX \\
\hline solitaire & boxing & roulette & theater & snowboarding \\
\hline crosswords & billiard & lottery & performance & alpinism \\
\hline puzzles & football & gaming & & \\
\hline & chess & & & \\
\hline
\end{tabular}

Developing talent for the Video Game industry in Colombia: Design and development issues. Álvaro Hernán Galvis, Pablo Figueroa Forero y Marcela Díaz Osorio. 
Ways of playing (ibid, p. 39-40):

- Paidia refers to spontaneous manifestations of the instinct of play. It relates to our capacity to improvise and to the joy of living things. It is the elemental need for activity and commotion that appears as the desire to touch everything, to grasp, to test things, to smell and later forget: a cat tangling itself in a ball of yarn, a dog shaking water off, the newborn smiling at a rattle.

- Ludus refers to a complementary tendency - a growing necessity to submit to arbitrary conventions that are intentionally required and bothersome. Play becomes more and more confusing due to trickier obstacles and the fact that the goal is to make it harder for the players to reach their desired outcome. This is perfectly useless, yet it requires more effort, more patience, more ability or genius each time. When these conventions were introduced, the first named games appeared such as: leap frog, hide and seek, blind-man's bluff, playing with dolls. It was difficult for this to happen with paidia. Within ludus one fights against an obstacle, not necessarily against one or various competitors; this is the case of videogames, which can be considered ludus for they build on interactive challenges framed by rules within scenarios that benefit from multimedia capacity of high performing computers and networks. As is evident, there are many types of videogames, and a framework to classify them is needed in order to better understand opportunities in the videogame sector.

Roles that characterize play (ibid, pp. 67-69)

- Agon, games of competition, e.g, soccer, chess--include competitions in which an artificial equality of conditions are created so that the opponents can confront one another under ideal conditions. It is possible to assign a precise and unarguable victory over the winner. Most videogames belong to this category. The practice of agon assumes sustained attention, appropriate training, assiduous effort, and desire to win. It demands discipline and perseverance. The corruption of agon is tied to violence, and the desire for power.

- Alea, games of chance, e.g., roulette, lottery. In these games the arbitrariness of chance constitutes the main challenge in the game. In contrast to agon, alea denies effort, patience, and ability. While in agon the player can vindicate himself, in alea he renounces his will and abandons himself to destiny. Randomness in videogames brings tension and excitement. The corruption of alea is tied to superstition and fetishism.

- Mimicry, games of representation or pantomime, e.g., being a pirate, roles. Every game presupposes the temporary acceptance of a closed universe, one that is conventional and in some ways fictitious. The pleasure comes from being someone else and in passing oneself off as someone else. Customizing the avatar and its behaviour in a videogame gives a sense of control to the user, makes $\mathrm{him} / \mathrm{her}$ "feel" the role s/he is playing. The corruption of mimicry is tied to alienation and unfolding of the personality.

- Ilinx, games of dizziness, e.g, acrobatics, mountain climbing. An attempt to temporarily destroy the stability of perception and inflict an exciting sense of panic to the lucid conscience. It has to do with reaching a sort of spasm, of trance or bewilderment that annihilates reality with a sudden sovereignty. Horror

Developing talent for the Video Game industry in Colombia: Design and development issues. Álvaro Hernán Galvis, Pablo Figueroa Forero y Marcela Díaz Osorio. 
and science fiction videogames provide this type of experience. The user becomes part of the argument. The essential part is the search for a specific thrill of momentary panic defined by the end of the vertigo. The corruption of Ilinx is tied to alcoholism and drugs.

The above sub-classifications permit us to generate a more detailed classification, keeping in mind the way play is done and the role one plays in the game. Even more than a mere matrix, Table 1 should be thought of as a continuum between two extremes (paidaia and ludus) and the relationships between the four roles. It is evident that some play combines the roles. For example, agon-alea is combined in games of cards, which falls within the world of rules once it goes beyond dealing at random. Mimicry-ilinx combine in games of rhymes and within feats of improvisation. However, perhaps it is less evident that not all combinations exist; agon-illinx and alea-mimicry are incompatible, for instance. According to Galvis, (2000, p. 18), within this classification, the spirit of play is at the forefront and in all of play's distinct manifestations, ingenuity, improvement, and invention are stimulated.

Video games are not the exception. Reports cited by Ponnada and Kannan (2012) state that a large craze for ludic engagements, in particular in mobile environments, has made the video game an industry of broad scope and visibility. According to these authors, statistics from 2012 show that around $70-80 \%$ of all mobile downloads were composed of mobile games, and survey reports in 2012 predicted a rise of up to US\$54 billion in revenue in mobile gaming by 2015 . The same report indicates that

"the primary characteristics of a mobile game that make it enjoyable are its content, storyboard, rewards, graphics, sound effects and user-experience. While designing such a game, a designer should accommodate these characteristics in order to create an engaging experience that can attract more gamers, leading to the success of the product" (Ponnada and Kannan, 2012, p. 244).

\section{Background studies and Curriculum design}

Curriculum design goes beyond technical elements that define the type of person who will be educated, and is created in the framework of a given socio economic niche. It follows a strategic thinking process that illuminates decision-making about strategies to achieve competencies that program beneficiaries should acquire.

\section{Background studies}

A study by the Cámara de Comercio de Bogotá, Centro de Estrategia y Competitividad CEC (2012) concluded that Colombia faces a great challenge if exports from the animations and video game industry are to grow. The Colombian AVGS needs to be prepared for high volume production of digital content that complies with international standards. It also should systematically prepare multidisciplinary groups ready to assume the different roles that AVGS industries require. 
Building on the above results, a study by Restrepo, Cruz Moreno and Rolón Domínguez (2012) reviewed both formal and informal opportunities for learning AVGS roles in the national and international arena. By the year 2012, most AVGS local learning opportunities in Colombia were short face-to-face curricular sequences called "diplomados". Most of them prepared participants to assume different roles in the AVGS without collaboration from other types of roles. Few advanced degree and mostly face-to-face programs were offered locally. Absent from these programs was collaborative video game design and production, strategies that are present in internationally accredited programs ${ }^{1}$, such as illustrated in IGDA International Game Developers Association (2008, pp. 36-44) ${ }^{2}$ and in ESA Entertainment Software Association (2015). An interdisciplinary, project-based approach is a constant in internationally accredited programs, and while most of these programs are offered faceto-face, some of them are offered in a blended modality.

In order to explore the potential and requirements of blended learning programs (bLearning) a study by Galvis and Pedraza (2013) was consulted. It showed that there is not a universal recipe for success in eLearning or bLearning higher education programs; on the contrary, each program must reflect the institutional mission and vision, take into account special characteristics of the target population and special characteristics from each of these learning modalities, and create the appropriate means to help participants acquire knowledge and develop relevant competences. This study highlights organizational, educational and technological issues that allow bLearning o eLearning creators to deal with operational and strategic critical success factors. These were derived from a benchmark studying bLearning success case studies from leading American and European universities.

\section{Curriculum design}

In response to the need to fill a gap in talent development for the AVGS in the higher education sector in Colombia, a systematic curricular design for a Video-game Development Specialization was conducted by the Systems and Computer Science Department at University of los Andes. Its implementation was authorized by the Ministry of Education (2013). Each component of the program addresses specific shortcomings in the local offerings as well as the quality demands of the international market.

\section{Educational goals}

This graduate program seeks to provide formative answers to educational needs at the AVGS, in the framework of an expanding international market that demands mobile, networked and stand-alone solutions that run under multiple computing platforms and in which multidisciplinary groups are required to participate.

\footnotetext{
1 See IGDA Curriculum Framework, at http://gameprogramreview.com/files/igda2008cf.pdf Curricular emphasis of AVGS related post-graduate international programs: Management, production, design, animation, programming, sound, art
} 


\section{Applicant Profile}

This graduate program has been created for professionals already involved in the VG industry, or for those willing to participate in it as creators and entrepreneurs. Applicants should have background in one of the following areas: systems and computer engineering; electronic engineering; multimedia design and production; digital or graphic design; sound or music engineering. They are expected to be adult learners and will likely both work and study. They have access to computing and communications technologies at work and at home. They are expected to be selfmotivated learners willing to improve their professional skills. Consequently, the program takes into consideration that future participants are in need of a blendedlearning modality that helps them overcome situational barriers for learning (e.g., time, space, access to learning resources) as they are not full time students.

\section{Graduate Profile}

Graduates from this certificate program will be able to: 1) contribute to multidisciplinary teams that design and develop video games; 2) assume technical roles according to their preparation as programmers, artists, musicians or audio experts; 3 ) take on managerial roles, which are described below.

The following chart depicts how three different types of participants will become members of a video-game production team in which each different complementary role adds value to a multidisciplinary production team.

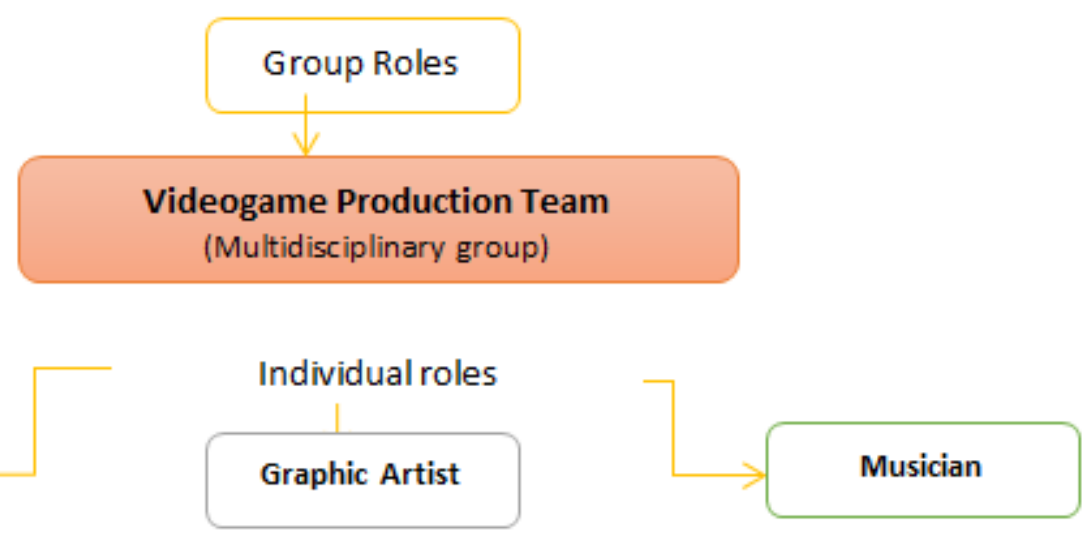

Figure 1. Group and individual roles for video game production

\section{Competencies per role}

Table 2 below shows the competencies for each role in the multidisciplinary team. A student in this program must choose a technical role (i.e., programmer, artist, and musician). Along with technical training in specific areas, each student will receive instruction in content related to managerial roles such as production and 
entrepreneurship, so all students are capable of both the mechanics of technical tasks as well as the direction and development of their own games.

Table 2. Competences per role

\begin{tabular}{|c|c|}
\hline Role & Competencies \\
\hline $\begin{array}{l}\text { Video game } \\
\text { production team } \\
\text { (group-based } \\
\text { entrepreneurship } \\
\text { roles) }\end{array}$ & $\begin{array}{l}\text { - Generate new digital content related to video games (VGs), } \\
\text { such as commercial videogames, serious games, interactive } \\
\text { books, and simulators. } \\
\text { - Define and implement VG business models } \\
\text { - Plan and oversee VG production processes } \\
\text { - Become VG executive producers } \\
\text { - Propose marketing and usability techniques for VGs } \\
\text { - Coordinate multidisciplinary VG production teams } \\
\text { - Actively assume their production role in VG production } \\
\text { - Apply VG design techniques }\end{array}$ \\
\hline $\begin{array}{l}\text { Programmers } \\
\text { (individual } \\
\text { technical roles) }\end{array}$ & $\begin{array}{l}\text { - Program and optimize VG performance } \\
\text { - Use programming tools for VG development } \\
\text { - Assess and use state-of-the-art technologies for VG } \\
\text { development }\end{array}$ \\
\hline $\begin{array}{l}\text { Graphic artists } \\
\text { (individual } \\
\text { technical roles) }\end{array}$ & $\begin{array}{l}\text { - Use digital graphic tools to conceive, design and produce } \\
\text { VGs } \\
\text { - Conceive and implement aesthetic and graphic VGs } \\
\text { components } \\
\text { - Propose visual interfaces for VGs }\end{array}$ \\
\hline $\begin{array}{l}\text { Musicians } \\
\text { (individual } \\
\text { technical roles) }\end{array}$ & $\begin{array}{l}\text { - } \text { Create sound and music effects for VGs } \\
\text { - Apply sound and music creation tools to VG development }\end{array}$ \\
\hline
\end{tabular}

\section{Learning principles behind videogame design}

Successful video games usually combine design principles that keep with a variety of psychological approaches to human learning. In order to understand how this may work, it is very useful to build on the concept of the microworld, which is intimately related with the idea of video games. It can be understood as ludus that build on the video, sound, and interactive capacities of mono or multi-user computing systems.

According to Rieber (1996, p. 45) a microworld is a small, but complete, version of a domain of interest. People do not merely study a domain in a microworld, they "live" the domain. One can act in the simulated world and get feedback from it as an artificial microworld models some system or domain for the user. A classic example is a flight 
simulator. In this microworld the artifact behaves as the airplane. It models the microworld of the pilot's cabin.

Microworlds are built with arguments that are not necessarily tied to the domain of interest. For instance, in the common game "hang man" where the user tries not to be hung by means of giving right answers to questions, any content can be superimposed onto this fantasy. This extrinsic microworld is not related to the concepts being practiced. This example serves to illustrate how behavioristic principles (Skinner, 1954) apply in game design since immediate feedback is provided for each decision made by the player. In the videogame scenario one can "see" the effect of each answer, and the evolution of the overall argument is reflected in the current status of the game. In the example, extrinsic motivation and explicit rewards occur when one realizes his actions lead to being hung, or not.

On the other extreme, endogenous fantasies comprise the content in intrinsic microworlds. Rieber mentions (ibid, p.50) that one cannot tell where the game stops and the content begins; if the player is interested in the fantasy, he or she will be interested in the content. A good endogenous fantasy is an important first step towards intrinsic motivation. A good example is $\mathrm{TIM}^{3}$ - The Incredible Machine-which is a game where the player solves real-life puzzles by means of combining different types of simulated machines and background artefacts. Constructivist learning principles (Piaget, 1972) are evident in this game: there is intrinsic motivation to solve an authentic problem. There is an epistemic conflict as long as each puzzle generates a state of disequilibrium (i.e., mental structures not in balance), and either the conflict is resolved in keeping with an established mental structure (i.e., assimilation), or a new structure is formed (i.e. accommodation). A third possibility is that the conflict remains unresolved and no learning takes place.

A third psychological approach worth mentioning in the video game design arena is the Flow Theory developed by Mihaly Csikszentmihalyi (1990). Flow theory gets its name from the feeling induced by certain activities. Many adults have described a state of extreme engagement, happiness and satisfaction when they are absorbed doing certain activities. In this state one seems to "flow" along with the activity in a spontaneous and almost automatic manner (ibid, p.4). According to Rieber (1996, p.48) flow derives from activities that provide enjoyment, and happens when an activity meets one or more of the following eight components: 1) Challenge is optimized; 2) Attention is completely absorbed in the activity; 3) The activity has clear goals; 4) The activity provides clear and consistent feedback as to whether one is reaching the goals; 5) The activity is so absorbing that it frees the individual, at least temporarily, from other worries and frustrations; 6) The individual feels completely in control of the activity; 7) All feelings of self-consciousness disappear; and, 8) Time is transformed during the activity (e.g. hours pass without noticing). Not surprisingly, these components are quite consistent with characteristics of video gaming, since what makes these interactive devices successful is the level of engagement and satisfaction generated by their use.

3 Contraption Maker is the new version of TIM; it is available for free, for educators, at http://contraptionmaker.com/education

Developing talent for the Video Game industry in Colombia: Design and development issues. Álvaro Hernán Galvis, Pablo Figueroa Forero y Marcela Díaz Osorio. 


\section{Curricular decisions}

The curricular decisions for the video gaming certificate program were based on the aforementioned needs to appeal to the target population, be flexible, be rich in diverse learning environments and to be fully tuned with the output profile. Thus, this program will be offered in blended modality (alternating face-to-face with online activities), with combination of individual with group activities, and articulating problem-based with project-based teaching strategies.

The program adopted and adapted a 3 cycles $x$ ( 5 weeks online +1 week face-to-face) of learning experiences] formula for the blending of online and face-to-face activities; this approach is successfully being used at the University of los Andes. During the semester there are three cycles of five online learning weeks followed by two day long face-to-face interactions with faculty and tutors at the University of los Andes during the last week of the cycle. There is an initial meeting to begin and become familiar with this process. Flipped-classroom design was used for each of the courses. While studying online, participants have access to curriculum materials that help them appropriate basic concepts from readings, video or audio clips, and websites or digital materials. The aim of this component is that students acquire the fundamental concepts and demonstrate their use in context. Students are required to submit evidence of their appropriation of concepts via the web platform where the courses are nested throughout the 5 weeks that precede the face-to-face meeting. Feedback is provided either from the computer on close-ended questions, or from peers on open ended questions. These are complemented by "facilitation from the side" (in contrast with "facilitation from the center") from the part of course directors and tutors. As a result, face-to-face interaction focuses on building upon already-acquired concepts via interaction such as the discussion of cases, solution of problems, or work on projects. In this dynamic, the course director's role is to lead and nurture discussion and to help participants reflect on their own ideas and learn from others' ideas.

We defined two types of courses: those that develop group-based entrepreneurship roles and competencies, and those that develop individual technical roles. The first type of course is a collaborative project-based experience that requires participation of different type of technical roles. Each of these courses is devoted to fully understanding concepts that students will need to become entrepreneurs. The second type of course is based on hands-on experiences where each of the participants must learn and apply techniques that will add value to the solution of a VG production challenge depending on his/her expected role in the VG production process.

The VG certificate program ends with a capstone course in which small multidisciplinary groups apply "design thinking" and "agile methodologies" to the development of a video game aimed at a given target population.

Each cohort is expected to invest a year in the VG Development Certification Program. During the first and second semester, students take two theoretical courses and one technical workshop, both of which are problem-based courses. About six collaborative, parallel activities in videogame prototypes happen before the final project (capstone course) allow students to build competencies while they explore possible themes for their graduation project. Here they submit a group proposal. During the second semester

Developing talent for the Video Game industry in Colombia: Design and development issues. Álvaro Hernán Galvis, Pablo Figueroa Forero y Marcela Díaz Osorio.

Página 14 de 23 
they are required to participate in their "final project" course while they complete other courses which involve both individual and group responsibilities.

\section{Risks and challenges of curricular decisions}

The implementation of these curricular decisions is not an easy task for different reasons. What follows is a pedagogical reflection that assists in understanding risks and challenges of these choices.

- Course authorship: VG development is a multidisciplinary task in which practitioners do not necessarily have an academic background nor do academics necessarily possess sufficient practical experience. Consequently, our certification program seeks to address these potential deficiencies by inviting both university faculty and experts from VG and related fields to be course authors.

- Active learning at a distance: Conventional models for online or blended teaching do not fit with the active learning curriculum design since conventional eLearning is faculty-centered, whereas non-conventional eLearning is student and/or group-centered (Galvis \& Pedraza, 2013). Thus, having content experts with either face-to-face or online learning experience was not enough to assure active learning in blended environments. A strategic alliance with ConectaTE ${ }^{4}$, the Center for Technological and Educational Innovations at the Universidad de los Andes, helped overcome the hurdle. The ConectaTE team facilitated the production of the blended course using a big-ideas focused methodology that was fully aligned with the proposed curricular design. As will be explained later, course production was done around big ideas and guiding questions, which framed conceptual learning; authentic problems served as motivators of inquiry and application of knowledge. All of these are fully supported with learning technologies relevant for each course (Galvis \& Pedraza, 2012).

- Individual differences in background and interests: A curriculum design that promotes collaboration among three type of specialists is at risk when some participants do not have required background knowledge or when there is not a balanced number of specialists to conform manageable VG production teams. We considered the first possible difficulty by allowing students to take entrylevel courses that prepare participants for active engagement in multidisciplinary teams. We suggest completion of these courses before the curricular sequence starts. They include: (1) programming, which deals with VG programming concepts and tools, as well as with modern VG architectures; (2) graphic arts, which introduces graphic design concepts, color theory, typography, as well as visual composition; (3) music, which introduces participants to music composition and digital music. Concerning the second risk, we have designed special scholarships for outstanding students in certain roles that could be in high demand, so they can provide support to group in need of participation from a given role perspective.

$4 \quad$ See http://conectate.uniandes.edu.co

Developing talent for the Video Game industry in Colombia: Design and development issues. Álvaro Hernán Galvis, Pablo Figueroa Forero y Marcela Díaz Osorio.

Página 15 de 23 
- Production and testing time: Experience has shown that blended learning programs can be at risk when they are in need of more than $20 \%$ of adjustment while they are implemented (Galvis \& Pedraza, 2013, p. 32). With this in mind, we decided to produce and conduct one-on-one review for VG Development courses in two sets, each of them including all the courses to be offered in a given semester. We also decided to field-test curriculum materials for the first semester by using part of them in "Jump Camp", an online experience where young adults willing to learn about VG production got scholarships from MINTIC, the Technology and Communications Ministry. Feedback collected was the basis for adjusting course materials. We have not field-tested the full curriculum design, but it is expected to be done in the first offering of the certification program.

\section{Instructional Design and production of digital curriculum materials}

Curriculum materials were designed and produced using an interdisciplinary strategy. Faculty in charge of each of the courses interacted with pedagogy and instructional technology specialists, under the leadership of a course creation director.

\section{Instructional design}

The "big ideas" approach to the design of instruction (Galvis \& Pedraza, 2012) was selected as methodology to refine each one of the VG specialization courses. This design approach helps to focus course units on fundamental concepts rather than on topics. It promotes use of authentic performance as evidence of learning, and fosters technology-based active learning. As a consequence, this methodology requires changing the mindset of course creators at least in four aspects:

(1) Order in which the design is done. "What to teach" is established first and "how to assess performance" is decided upon after this is clear. Only then, "how to promote learning" (methods and means to teach) is established.

(2) Focus of the design. Fundamental concepts that express big ideas are used to organize and develop content, instead of thematic or content-based division of learning units.

(3) Use of authentic performance tasks. Real life problems and corresponding rubrics are used to assess big ideas instead of conventional assessment methods like quizzes and exams.

(4) Use of active learning methods and technology. These are integrated to promote knowledge acquisition and concept appropriation.

An illustration of such principles in action is the case of the "Videogame negotiation and entrepreneurship" course. This course is focused on studying how video game production and commercialization can become a successful business. As is shown in Table 3, this course is organized around three big ideas, each of them with enduring understandings, learning outcomes, and identification of student background (previous concepts and wrong concepts).

5 See Jump Camp 2015 initiative at http://vivelabs.virtual.uniandes.edu.co/

Developing talent for the Video Game industry in Colombia: Design and development issues. Álvaro Hernán Galvis, Pablo Figueroa Forero y Marcela Díaz Osorio. 
Table 3. Example of What to teach specification

\begin{tabular}{|ll|}
\hline Concepts: Big ideas / Fundamental concepts $\rightarrow$ Enduring understandings \\
\hline 1. & $\begin{array}{l}\text { MINDSET: Videogame entrepreneurs identify business opportunities by } \\
\text { observing their potential clients }\end{array}$ \\
\hline 1.1. & There are different type of videogamers with different motivations \\
\hline 1.2. & $\begin{array}{l}\text { Effectuation is a logic of entrepreneurial expertise that can be used in highly } \\
\text { unpredictable start-up phase of a venture to reduce failure costs }\end{array}$ \\
\hline 2. & VALUE EXCHANGE: Businesses ought to generate and exchange value \\
\hline 3. & $\begin{array}{l}\text { BUSINESS MODEL: Business model deals with how to generate, capture, and } \\
\text { exchange value in business }\end{array}$ \\
\hline Behaviours/expected outcomes for Big Idea 1 \\
\hline $1.1 \quad \begin{array}{l}\text { Videogame entrepreneurs are able to define key characteristics of their potential } \\
\text { clients and the value that different types of video games could add to them }\end{array}$ \\
\hline $1.2 \quad \begin{array}{l}\text { Videogame entrepreneurs can envision and express how they could achieve } \\
\text { imagined ends by themselves or with stakeholder commitments }\end{array}$ \\
\hline Student background (expected previous concepts or wrong concepts): None \\
\hline
\end{tabular}

Source: Estrada, Felipe (2015)." Videogame negotiation and entrepreneurship course, module 1"

The "Final Project" is a capstone course where previously learned "agile methodology" for software creation and interdisciplinary work promoted through the certification are put in practice. Table 4 summarizes the assessment system defined for this course.

Table 4. Example of authentic performance and corresponding rubrics

\begin{abstract}
Authentic performance statement
Working as an interdisciplinary team (software engineers, artists, graphic designers, and musicians) and making use of "agile methods" to interact with clients and adjust development plans based on results of the interaction, each team should produce a functional video game that satisfies expectations. Five (planning $\rightarrow$ development $\rightarrow$ delivery) three week cycles should be followed. Feedback will be provided weekly by the course director.
\end{abstract}

\title{
Course evaluation system, deliverable weights
}

Video game current version, documentation, and presentation: $20 \%$ for each of cycles 1 , 2,3. Video game final version, documentation, and presentation: $40 \%$ 
Table 5. Course evaluation rubrics for each cycle assessment

\begin{tabular}{|c|c|c|c|c|c|}
\hline Component & Weight & $\begin{array}{l}\text { Superior } \\
\text { performance }\end{array}$ & $\begin{array}{l}\text { Medium } \\
\text { performance } \\
(3 \text { to } 3.9 \\
\text { points) }\end{array}$ & $\begin{array}{l}\text { Low } \\
\text { performance } \\
\left(\begin{array}{ll}0.0 \text { to } 2.9 \\
\text { points })\end{array}\right.\end{array}$ & $\begin{array}{l}\text { Weighted } \\
\text { average }\end{array}$ \\
\hline Documentation & $60 \%$ & $\begin{array}{l}\text { Presents current } \\
\text { status, identifies } \\
\text { risks, what } \\
\text { works and what } \\
\text { is pending, } \\
\text { adjustments to } \\
\text { be done }\end{array}$ & $\begin{array}{l}\text { Most of the } \\
\text { document is } \\
\text { OK, but there } \\
\text { are things to be } \\
\text { fixed } \\
\text { concerning } \\
\text { project status, } \\
\text { risks, or to do } \\
\text { planning. }\end{array}$ & $\begin{array}{l}\text { Most of the } \\
\text { document is } \\
\text { unacceptable, } \\
\text { it lacks project } \\
\text { status, risks, } \\
\text { and/or to do } \\
\text { planning. }\end{array}$ & \\
\hline $\begin{array}{l}\text { Software } \\
\text { performance }\end{array}$ & $20 \%$ & $\begin{array}{l}\text { Software runs as } \\
\text { students have } \\
\text { documented. If } \\
\text { this is not } \\
\text { possible for } \\
\text { technical } \\
\text { reasons, video } \\
\text { capture evidence } \\
\text { should be sent to } \\
\text { the teacher. }\end{array}$ & $\begin{array}{l}\text { Some aspects } \\
\text { of the software } \\
\text { do not run as } \\
\text { announced }\end{array}$ & $\begin{array}{lr}\text { Software } & \text { does } \\
\text { not run } & \text { but } \\
\text { there } & \text { are } \\
\text { elements } & \\
\text { worth } & \\
\text { rescuing } & \end{array}$ & \\
\hline Presentation & $20 \%$ & $\begin{array}{l}\text { A live } \\
\text { presentation } \\
\text { includes all } \\
\text { aspects of the } \\
\text { project, shows } \\
\text { good planning } \\
\text { and } \\
\text { implementation, } \\
\text { students respond } \\
\text { wisely and } \\
\text { clearly to } \\
\text { questions by the } \\
\text { audience }\end{array}$ & $\begin{array}{l}\text { Most of the } \\
\text { live } \\
\text { presentation } \\
\text { components } \\
\text { are satisfactory } \\
\text { but one or two } \\
\text { of them need } \\
\text { adjustment, } \\
\text { e.g., timing, } \\
\text { planning, } \\
\text { resources, } \\
\text { interaction }\end{array}$ & $\begin{array}{l}\text { The } \\
\text { production } \\
\text { team is not } \\
\text { properly } \\
\text { prepared to } \\
\text { present and/or } \\
\text { to respond to } \\
\text { questions } \\
\text { from the } \\
\text { audience }\end{array}$ & \\
\hline
\end{tabular}

Source: Buchanan, Felipe (2015). "Final project" course.

As was mentioned before, because of the blended nature of the specialization, active methods are always in place. In this regard, each of the courses makes use of flippedclassroom design to promote knowledge acquisition from diversity of digital sources. 
Students should get essential concepts by themselves and through online interaction with others, while face-to-face interaction is mostly devoted to workshops and discussions with faculty participation. Course activities usually combine expository means (PDFs, videos, web pages) with active means (digital production tools, simulators, games) with interactive means (online discussions, group projects).

\section{Production of digital curriculum materials}

Moodle was selected as learning management system for this specialization ${ }^{6}$ and Mahara $^{7}$ as the ePortfolio management system. Both systems are available and well supported at the University of los Andes.

Graphic design was done to reflect the essence of the program (see Figure 2) and icons were created to consistently visualize each of the actions allowed in the learning system.

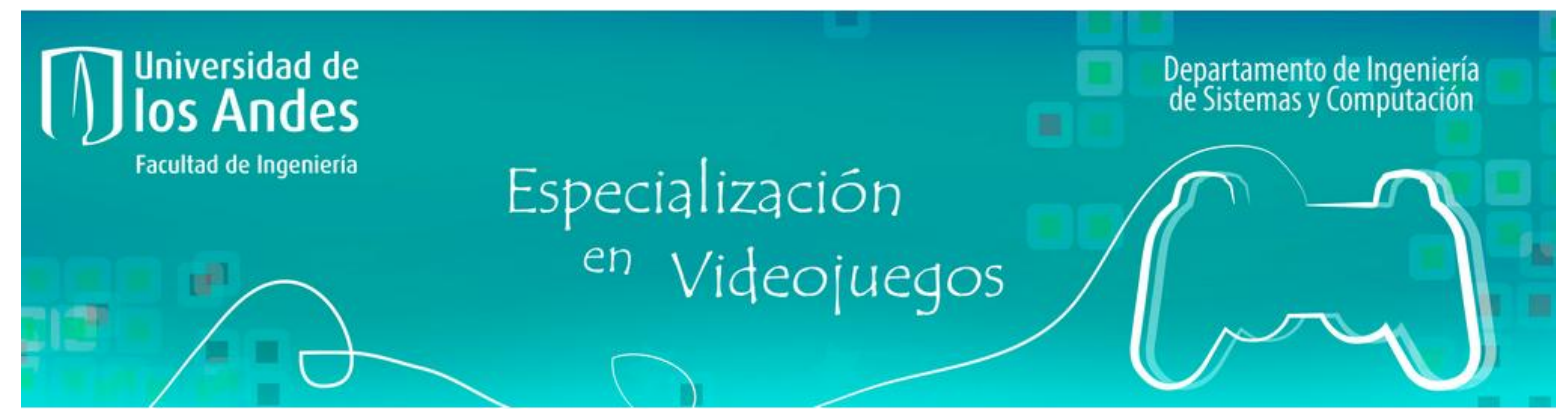

Figure 2. Video game specialization banner

Each one of the courses has a similar structure, reflecting big ideas to be achieved. For instance, Figure 3 reflects "Negotiation and entrepreneurship in video games, module $1 "$ course structure.

\begin{tabular}{|c|c|c|c|}
\hline Permanente & Mindset & Intercambio de Valor & Modelo de Negocio \\
\hline
\end{tabular}

\section{Figure 3. Course navigation structure following big ideas}

The "permanente" tab takes users to resources and interaction spaces that are used throughout the course. The rest of the tabs take users to weekly activities under the corresponding big idea.

6 See http://moodleinstitucional.uniandes.edu.co/course/index.php?categoryid=6

7 See http://eportafolio.uniandes.edu.co/ 


\section{Lessons learned}

There are quite a few lessons learned from the creation of this new program at the design level, at level of the creation of curriculum materials, and also concerning marketing and promotion. Here we describe those that could have value for other institutions that are developing new programs.

At the level of program design, it is important to consider all factors in the context. We took into account government regulations for blended programs, the mission and existing programs at our university, similar programs in our country and elsewhere, and our videogame industry and its relation to the global market. Although a synergy between government, industry, and academia is required in order to foster new industries, at the beginning it is always a struggle. Colombia's government has been pushing for the creation of new industries related to Digital Contents in the last 6 years, and although there have been great results for some Colombian companies, our entire industry is still too small and too young according to international standards. Our program had to be designed not for an existing market and at once for the market we would like to have in some years. Specific needs from our national industry were also considered, such as their indie nature, their need to sell their products in global markets, and current opportunities and challenges. Finally, it is important to explain how our program compares to internationally known ones, so studying such programs to find similarities and differences is essential.

At the level of creation of curriculum materials, we struggle with new competencies that blended learning requires from faculty members. Our professors are experts in their fields with great experience in teaching traditional classes, but they were new to the preparation of blended courses. Although the university provided funding and support for the creation of curriculum materials and for expert coaching on blended methodologies for learning, such funding was short for other equally important elements: material testing and tuning, graphic design for the courses' website, faculty members' time to redesign their courses for this new format. In general, there is some tendency to treat blended learning as just another way to teach, but it really requires more preparation and work than the preparation of traditional courses and programs.

At the level of marketing and promotion, videogames generate passion in many students, so it is easy to generate interest by mentioning this topic. However, it is very different to have passion for playing videogames than for building videogames. It is important to educate future students in the differences between these concepts and help them explore their future as videogame developers. We also place emphasis on the different roles that professionals in the videogame industry may have, so they can align their own strengths to what we offer for each role in our program.

Our program is on the verge of its launch and we plan to improve its future outcomes with the experience we have learned in related programs. The nearest reference for us is Jump Camp (see http://jumpcamp.virtual.uniandes.edu.co), a 120 hour informal program on videogame development sponsored by our Ministry of Information Technology. Since the local business industry in videogames is still young, we have learned that government incentives could help to grow such a sector. While most of those incentives have been directed towards development and commercialization of new

Developing talent for the Video Game industry in Colombia: Design and development issues. Álvaro Hernán Galvis, Pablo Figueroa Forero y Marcela Díaz Osorio. 
videogames, we believe that more people could migrate to this sector if there were incentives for training. This is a scheme we are working on. We also want to work with interested companies to facilitate certification programs to our students inside our curricula. There are still issues related to the average wage in this industry compared with other industries that require the same professionals, in particular in the case of programmers. Whereas this could be an obstacle for some professionals, others are more interested in pursuing a job that they like rather than one that is better paid, so we have concentrated our efforts on this feature. In the future, we plan to make this advantage for interested professionals more evident.

Presentación del artículo: 29 de diciembre de 2015 Fecha de aprobación: 3 de marzo de 2016 Fecha de publicación: 30 de abril de 2016

Galvis, A.H., Figueroa, P. y Díaz, M. (2016). Developing talent for the Video Game industry in Colombia: Design and development issues. RED. Revista de Educación a Distancia. 49(4). Consultado el (dd/mm/aaaa) en http://www.um.es/ead/red/49

\section{References}

Annetta, L. A. (2010). The "I's" Have It: A Framework for Serious Educational Game Design. Review of General Psychology, 14(2), 105-112. doi:10.1037/a0018985

Caillois, R. (1986). Los juegos y los hombres. La Máscara y el vértigo. México, DF: Fondo de Cultura Económica.

Cámara de Comercio de Bogotá, Centro de Estrategia y Competitividad CEC. (2012). Oferta Nacional de la Industria de Contenidos Digitales. Bogotá, Colombia: Uniandes, MinTIC, Proexport. Retrieved from http://juegos.virtual.uniandes.edu.co/wp-content/uploads/2013/04/Oferta-nacionalde-la-industria-de-contenidos-digitales-2013.pdf

Cámara de Comercio de Bogotá; Centro Nacional de Consultoría. (2010). Diagnóstico y plan de acción para la industria de la animación digital y videojuegos en Bogotá. Bogotá, Colombia: Autor. Retrieved from http://culturayeconomia.org/wpcontent/uploads/Diagnóstico-ADVJ.pdf

Csikszentmihalyi, M. (1990). Flow: The psychology of optimal experience. New York, NY: Harper \& Row.

ESA Entertainment Software Association. (2004). Top ten industry facts. Washington, DC: Author.

ESA Entertainment Software Association. (2015). College Video Game Programs. Retrieved from ESA Entertainment Software Association: http://www.theesa.com/about-esa/courses-certificates-degree-programs/ 
Galvis, A. H. (2000). Play, puzzles and creativity: Learning engines for the Knowledge Society. Retrieved from http://playspace.concord.org/Documents/Play\%20puzzles\%20and\%20creativity.pdf

Galvis, A. H., \& Pedraza, L. C. (2012). Rediseño de cursos para la comprensión de grandes ideas e integración de tecnologías para el aprendizaje. Revista de Tecnología de Información y Comunicación en Educación, 2, 11-45. Retrieved from http://servicio.bc.uc.edu.ve/educacion/eduweb/vol6n2/art1.pdf

Galvis, A. H., \& Pedraza, L. C. (2013). Desafíos del bLearning y el eLearning en Educación Superior. In N. Arboleda Toro, \& C. Rama Vitale (Eds.), La educación superior a distancia y virtual en Colombia: Nuevas Realidades (pp. 113-154). Bogotá, DC: Virtual Educa y ACESAD.

Gaudiosi, J. (2014). How Helsinki evolved into a global video game hit factory. Retrieved from Fortune: http://fortune.com/2014/10/06/helsinki-video-games/

Huizinga, J. (1972). Homo Ludens. Buenos Aires, Argentina: Emecé Editores SA.

IGDA International Game Developers Association. (2008). IGDA Curriculum Framework: The Study of Games and Game Development. Game Education Special Interest Group. Retrieved from http://gameprogramreview.com/files/igda2008cf.pdf

Izushi, H., \& Aoyama, Y. (2006). Industry evolution and cross-sectoral skill transfer: A comparative analysis of video game industry in Japan, the United States, and the United Kingdon. Environment and Planning, 10, 1843-1861. doi:10.1068/a37205

Osborn, G. (2015). Irish game development poised to break out. Retrieved 07 29, 2015, from gamesindustry,biz: http://www.gamesindustry.biz/articles/2015-06-24-irishgame-development-poised-to-break-out

Piaget, J. (1972). The principles of genetic epistemology. New York, NY: Basic Books.

Ponnada, A., \& Kannan, A. (2012). Evaluation of mobile games using playbility heuristics. ICACCI - 2012 International Conference on Advances on Computing, Communications and Informatics (pp. 244-247). Chennai, T Nadi, India, August 3-5, 2012: ACM.

Restrepo, A. M., Cruz, N. Z., \& Rolón, B. H. (2012). Proyecto D.A.V.I.D - Análisis de la oferta académica en contenidos digitales. Bogotá, Colombia: Universidad de los Andes. Retrieved from http://juegos.virtual.uniandes.edu.co/wpcontent/uploads/2012/12/estudio_vdj_2.pdf

Rieber, L. P. (1996). Seriously considering play: Designing interactive learning environments based on blending of microworls, simulations and games. Educational Technology Research \& Development, 44(2), 43-58. Retrieved from http://lrieber.coe.uga.edu/play.html 
Skinner, B. (1954). The science of learning and the art of teaching. Harvard Educational Review, 24(2).

Sorensen, B. H. (2009). Concepts of Educational Design for Serious Games. Research, Reflections and Innovations in Integrating ICT in Education (pp. 278-282). Badajoz, Spain: Formatex. Retrieved from http://www.formatex.org/micte2009/volume1.htm

Tschang, F. T., \& Goldstein, A. (2004). Production and Political Economy in the Animation Industry: Why Insourcing and Outsourcing Occur. DRUID Summer Conference, 1-22. Elsinore, Denmark. Retrieved from http://www.druid.dk/conferences/summer2004/papers/ds2004-92.pdf

Universidad de los Andes, Departamento de Ingeniería de Sistemas y Computación (2013). Registro Calificado Especialización en Desarrollo de Videojuegos. Bogotá, Colombia: Autor.

Universidad de los Andes. Departamento de Ingeniería de Sistemas y Computación (2015) EGAMES Especialización en Video Juegos. Retrieved 06, 01, 2015, from Universidad de los Andes, Departamento de Ingeniería de Sistemas y Computación: http://sistemas.uniandes.edu.co/es/egames-general/generalidades 